\title{
IMPORTANCE AND THE IMPACT OF CAREER SERVICES IN PREPARING STUDENTS OF UNIVERSITY OF PRISHTINA FOR THE LABOR MARKET
}

\author{
Arlinda Beka, MSc \\ Faculty of Education, University of Prishtina \\ Manager, Career Development Centre \\ Prishtina, Republic of Kosovo \\ e-mail: arlinda.beka@gmail.com \\ Elmedina Nikoçeviq, MSc \\ Career Advisor \\ Career Development Centre, University of Prishtina \\ Prishtina, Republic of Kosovo \\ e-mail: elmedinan@gmail.com
}

\begin{abstract}
A b s tract
Career development for students of the University of Prishtina is one of the very important factors and a necessary for their professional development. Until 7 years ago, students of UP where not receiving any kind of help in advising or any kind of practical help that would help them in professional preparation for the labor market.

With the opening of Career Development Center for the first time there was an increasing awareness among students of University of Prishtina for career development. At the same time students started to realized the importance of professional preparation before they can approach to the labor market.

In this paperwork we will present the data collected from the research done with students of the bachelor level. The purpose of the research is confirmation of the role and the impact of the services provided through Career Development Centre in professional preparation of students.
\end{abstract}

Key words: Students, Professional internship, Labor market, teaching

\section{Introduction}

In a Europe where population is getting older Kosovo is an exception. Almost one third of Kosovo's population is under 15 years old and more than half are under 25 years old. 
A consistently high rate of unemployment among citizens of all ages is the most concerning aspect of Kosovo's labor market. A strong employment market is important to every economy, but the overall economic environment in Kosovo has resulted in few employment opportunities and generally poor conditions in the labor market.

In most countries labor market policies are intended to facilitate a proper allocation of labor resources and to develop the necessary human capital so as to maximize the labor contribution to growth (Abrahart and Verme, 2001). Labor market policies address problems in the labor market, but Kosovo they are not necessarily concerned with the most disadvantaged or those most exposed to risks in our society. An all inclusive employment policy that would facilitate youth access to the labor market does not exist in Kosovo. According to data from the Department of Work and Employment of the Ministry of Labor and Social Welfare of Kosovo the total number of the registered job seekers in June 2010 was 335,926 persons, a $77 \%$ decrease of unemployment registrations compared to 2009. Compared to 2009, the number of registered unemployed citizens represents an average of $37 \%$ out of $40 \%$ of the economically active population.

About $60 \%$ of the unemployed job seekers registered with the employment offices are listed as "unqualified" based on the level of education required for the available jobs. The data tells us that the highest rate of increase at employment office registrations are university graduates $6.2 \%$. 3245 person with university diplomas were registered as unemployed in June 2010. This category is considered to be more in danger of remaining unemployed for a longer period of time than those who are considered qualified on the basis of their level of education.

However, even graduates of the University of Prishtina face many difficulties entering the labor market. Although it is believed that a university education helps young people prepare for the labor market and find jobs easily many employers value work experience above education, and certainly value the combination of experience and education over just education.

Internships are an important way for students to gain needed experience in their field of study to better prepare them to qualify for employment. Regrettably some University departments do not offer well organized internships or other ways for students to gain the experience employers look for in hiring new employees. In addition, the lack of strategies to ensure internships are available to students in several faculties who have not regulated the issue of student internships contributes to the difficulties faced by graduates entering the labor market.

Most University of Prishtina graduates who have had a job interview are not offered a job due to the lack of work experience.

This problem is magnified by the lack of internships and other opportunities for practical work experience. Such opportunity during their studies allows the work experience to be integrated with their education. Instead, students are often obliged to find internships opportunities that are not integrated with their university education.

Because internships not only help student's professional development but are considered as work experience by employers a need exists for creating and 
developing internship programs for students in order to help them to enter labor market easily. In response to this need, the University of Prishtina and its Faculties have started to encourage further development of procedures and skills to prepare students for internship and strengthening their connection with employers through the University Career Development Center (CDC) which is considered a bridge between students and the labor market.

Employers complain that existing university education is not providing the skills and knowledge demanded by the labor market. In fact, CDC data shows that the majority of companies surveyed do not consider that university students are gaining the knowledge and skills required by the labor needs.

This lack of required knowledge and skills considered important by employers for employment has resulted in the need of university graduates to take additional professional training after graduation in order to increase chances of qualifying for employment following graduating.

Unfortunately, the needed programs for better preparing graduates to enter the labor market are limited. Initiatives for ensuring the required preparation for employment are hindered by a lack of or a weak regulation framework which would train first time job seekers and stimulate employment opportunities.

In 2010 Kosovo's Alliance for Business supported by the Ministry of Labor and Social Welfare conducted research to identify labor market needs. Researchers interviewed 685 employers. The results showed that employer's requests for workers are not presented at the public employment office as university graduates hesitate to visit them. Job vacancies usually are filled by employers hiring relatives and friends rather than vacancies being advertised. The finding of this research shows that the largest number of employment is done though "family and friends" (36\%), through public advertisement (31\%) and the smallest number through the "public employment services" (27\%).

\section{Professional training of students and graduates of the University of Prishtina}

Real and practical professional training for the labor market is a significant advantage for students seeking internships and graduates seeking employment. In addition to the practical and theoretical knowledge students are trained in researching the literature that impacts their profession and potential performance, preparing and delivering effective presentations.

Analysis of job advertisements in Kosovo's electronic and written media indicates that most of them require a work experience, English language knowledge and advanced computer skills in addition to a university diploma. However, the University of Prishtina does not offer students adequate computer or English language training programs required by the labor market student lack communication skills in English as well as computer skills both of which represent important criteria for employment Therefore the CDC is there to provide trainings for those students in the additional skills in order to prepare them fulfill the important criteria for employment. 
In addition, the CDC offers entrepreneurship training to help students learn to better fulfill the employment conditions and criteria as well as to gain further skills and knowledge.

Christopher Pratt, EdD and Jimmie Cochran Pratt, MPA from the "New Generations of Global Entrepreneurs" in their research "Global Citizenship through Work-Integrated Learning in the New Economy" (Volume 42, Number 2, ISSN: 1933-2130, Journal of Cooperative Education and Internships), have stated that: “...Work-integrated learning can provide this understanding. Outcomes of work-integrated learning for participating students include a meaningful perspective on their lives gained from the experience. These experiences shed light on how they fit into the world and the behaviors needed to succeed in that world. Early engagement by students in work-integrated learning along with courses in economics, philosophy, and history, can lead students to an understanding of what they can do for themselves, for their community, and foster their independent desire to do it. Students need to see that opportunities exist for them to contribute and that life-long learning, a key to being productive, is a personal investment in their future. In designing work-integrated learning programs we have the opportunity to help craft the future. By providing opportunities that inform, that stimulate the values of global citizenship, we can help students from their perceptions of what both they and their future can be..."1.

This work aids students in developing skills for identifying problems and alternative solutions, team work, conflict resolution, managing resources and mitigating risks, creativity, communication, leadership , time management, decision making, taking responsibility and other individual skills, that can lead to improved perspectives of employment.

Data of the year 2003 from RIINVEST indicates that the traditional academic education does not offer enough knowledge and skills required by the labor market. As a result, as long as the unemployed are not engaged in additional training their chances of finding immediate employment after graduations are low.

Within the Kosovo Ministry of Labor and Social Welfare there are eight Centers for professional training that address issues resulting from a lack of labor market skills and the needed training. According to data from the Department of Labor and Employment, and the Ministry of Labor and Social Welfare the total number of those unemployed that have completed professional training in the twelve months preceeding June 2010 was 3,052. This is a decrease of about $7.6 \%$ when compared to the twelve months preceding June.

Effective coordination and cooperation between high schools, the University, employers and the public employment services offices is crucial in order to provide a consistent focus, terminology, process and assessment of career development and job searching skills efforts.

\footnotetext{
${ }^{1}$ Christopher Pratt, EdD and Jimmie Cochran Pratt, MPA from the "New Generations of Global Entrepreneurs" "Global Citizenship Through Work-Integrated Learning in the New Economy“ (Volume 42, Number 2, ISSN: 1933-2130, Journal of Cooperative Education and Internships)
} 


\section{The role and influence of the $\mathrm{CDC}$ services in professional preparation of the UP students}

Often the teaching the plans and programs of the courses taught at the University do not offer students help and advice on how to approach the labor market. For this reason the University of Prishtina has a centralized Career Development Center that functions within the Office for Academic Development. The CDC offers information, resources and advice, and organizes different activities that give to aid students in their professional development. This Center is a bridge between students and institutions, international and domestic companies. It also helps the University and its Faculties better understand their student's needs and the quality of their professional preparation in terms of the labor market trends and demand.

The mission of the CDC includes maintaining regular contact and close cooperation with other institutions, government and non-government, public and private enterprises in order to keep students informed about possible internships during their studies which would help students better prepare for the labor market.

The academic program of the University focuses in developing and increasing the academic and intellectual capacity of students, but as is the case with most universities does not focus on student professional and career development. Therefore Career Development Center serves the vital need and purpose of addressing these needs and is in so doing increases the professional capacity and quality of the University of Prishtina. To achieve this mission the CDC offers career training, workshops, fairs, debates and similar activities that have proven as necessary for the professional development of students.

\section{Statement of the Problem}

The University of Prishtina is the public and largest university in Kosovo. It is composed of 17 Faculties and in 2007-08 enrolled 28,318 registered regular fulltime students and 3,706 part-time students. In the last academic year, 2010-11 this enrollment has been almost doubled.

As a result the University of Prishtina plays a significant role in moving Kosovo towards European integration. It has therefore been included in the contemporary education system and is one of the first in the region that has started reforms required according to the Bologna Process.

The role of the University in professional preparation of students for the labor market is very important as it directly impacts the career development of students by offering them solid preparation to enter the labor market. The University determines the level of professional development of students as well as the level of their professional achievement through assessment of the teaching plans and programs of the courses taught. 


\section{Objectives of the Study}

The objective of this research is to measure the level of professional preparation of students at the University of Prishtina for the labor market of Kosovo and the commensurate need for career development services

The purpose of this research is to determine the level of the professional preparation of University of Prishtina (UP) students, identifying student's needs for career development services and professional training, and determining their attitude related to the labor market demands. This research also offers possibilities for better understanding of the level of professional preparation of UP students, the role of career development services, and to assess the existing situation at the university regarding the condition for professional preparations as well as student's attitude about the labor market demands for employment.

The research of the level of professional preparation of the University of Prishtina students for the labor market and the conditions, in which it is offered by the University in their professional preparation, is necessary due to the high unemployment scale of the graduates of the UP and the high criteria of the labor market for employment. Results that come out of this research can be important and useful indicators of the needs and priorities required creating conditions and capacities for the professional preparation of students from the UP side.

\section{Research Methodology}

\section{Population and ratio}

This research was done among the Bachelor degree students of the University of Prishtina. It is focused on ten faculties including: Faculty of Philology, Faculty of Philosophy, Faculty of Economy, Faculty of Law, Faculty of Math and Natural Science, Faculty of Arts, Faculty of Education, Faculty of Electric and Computer Engineering, Faculty of Medicine and Faculty of Physical Education. Representing number is 1056 respondents as the population of this research. In order to increase the level of representation, samples are selected on the random way.

\section{Hypothesis of the research}

H. There is a need to offer career development for students of University of Prishtina with the purpose of training and preparing them for the labor market.

\section{Supporting hypothesis}

$\mathrm{H}_{1}$. Students of the University of Prishtina need additional professional training in order to fulfill labor market demands.

$\mathrm{H}_{2}$. Students of the University of Prishtina think that employing organizations are not happy with their professional preparation. 
Methods, techniques and instruments of the research - In order to research and study this issue well we have used the theoretical methodology, descriptive methodology, comparative and statistical methodology.

Researching techniques - In order to gather as much information as possible and make it easy for the respondents to answer the questions we have used the survey technique.

Research instruments - The data in this research has been gathered through a questionnaire. The questionnaire utilizes a Liker Scale in order to measure the students attitudes related to the issue.

\section{Findings of the Study}

Preparation of students for the labor market includes the use of career development programs that help students and graduates of University of Prishtina to gain abilities and skills for improved and effective access to the labor.

Interviewed respondents have been asked if they have a need for different career development i.e.: guidance for preparing a CV and cover letter, advice for job interviews.

Most of those interviewed (54.4\%) have responded that they need a lot of career development help in preparing a CV and cover letter, $32.4 \%$ have expressed that they need a little help, while $13.2 \%$ have answered that they do not need any help in writing a $\mathrm{CV}$ or a cover letter. (Table 1)

Table 1. Need for guidance for preparing a CV and cover letter $(\mathrm{N}=1056)$

\begin{tabular}{|l|c|c|c|c|}
\hline \multicolumn{1}{|c|}{ Question } & \multicolumn{3}{|c|}{ Answers } \\
& A lot & A little & $\begin{array}{c}\text { Not at } \\
\text { all }\end{array}$ & Total \\
\hline $\begin{array}{l}\text { How much do you need help in preparing a } \\
\text { CV and cover letter? }\end{array}$ & 575 & 342 & 139 & 1056 \\
\hline Percentage & $\mathbf{5 4 . 4}$ & $\mathbf{3 2 . 4}$ & $\mathbf{1 3 . 2}$ & \\
\hline
\end{tabular}

Regarding how much they need trainings for job interview, most of them (72.6\%) have answered "the need for a lot", 20.2\% expressed that they need "a little" while $7.2 \%$ said that they do not need any help with job interviews. (Table 2)

Table 2. Need for job interview trainings $(\mathrm{N}=1056)$

\begin{tabular}{|l|c|c|c|c|}
\hline \multicolumn{1}{|c|}{ Question } & \multicolumn{4}{|c|}{ Answers } \\
& A lot & A little & $\begin{array}{c}\text { Not at } \\
\text { all }\end{array}$ & Total \\
\hline $\begin{array}{l}\text { How much do you need job interview } \\
\text { trainings? }\end{array}$ & 767 & 213 & 76 & 1056 \\
\hline Percentage & $\mathbf{7 2 . 6}$ & $\mathbf{2 0 . 2}$ & $\mathbf{7 . 2}$ & \\
\hline
\end{tabular}


Regarding the services for providing professional training and different workshops, $73.6 \%$ of the interviewers expressed that they need a lot for this service, $20.6 \%$ expressed that they need "a little" while 5.8\% said they don't need this service. (Table 3)

Table 3. Need for participation in professional training and different workshops $(\mathrm{N}=1056)$

\begin{tabular}{|c|c|c|c|c|}
\hline \multicolumn{1}{|c|}{ Question } & \multicolumn{4}{|c|}{ Answers } \\
& A lot & A little & $\begin{array}{c}\text { Not at } \\
\text { all }\end{array}$ & Total \\
\hline $\begin{array}{l}\text { How much you need professional } \\
\text { trainings and different workshops? }\end{array}$ & 777 & 218 & 61 & 1056 \\
\hline Percentage & $\mathbf{7 3 . 6}$ & $\mathbf{2 0 . 6}$ & $\mathbf{5 . 8}$ & \\
\hline
\end{tabular}

Results show the need that students have for career services and see them as an opportunity for developing skills and abilities as well as increasing of the knowledge demanded by employers.

In the question if they think that are prepared for the labor market after graduation, $32.1 \%$ of the interviewed students strongly agree they are prepared, $38.7 \%$ agree, $13.6 \%$ disagree, $6.2 \%$ strongly disagree while $9.4 \%$ are undecided. (Table.04)

Table 4. Students preparation for the labor market after graduation $(\mathrm{N}=1056)$

\begin{tabular}{|l|c|c|c|c|c|c|}
\hline \multirow{2}{*}{ Question } & \multicolumn{7}{c|}{ Answers } \\
\cline { 2 - 8 } & SA & A & U & D & SD & Total \\
\hline $\begin{array}{l}\text { After graduation I'll be prepared } \\
\text { for the labor market. }\end{array}$ & 339 & 409 & 99 & 144 & 65 & 1056 \\
\hline \multicolumn{1}{|c|}{ Percentage } & $\mathbf{3 2 . 1}$ & $\mathbf{3 8 . 7}$ & $\mathbf{9 . 4}$ & $\mathbf{1 3 . 6}$ & $\mathbf{6 . 2}$ & \\
\hline
\end{tabular}

SA: Strongly Agree; A: Agree; U: Undecided; D: Disagree; SD: Strongly Disagree

The results show that a majority of students that were interviewed agreed that they are only a little or not at all prepared to enter labor market after graduation. In light of this data, it is clear to see why the majority of students interviewed agree that even after graduation with the Bachelor's degree they need additional training to fulfill the labor market demands. $32.8 \%$ of the respondents strongly agree with this, $36.8 \%$ agree, $15.0 \%$ disagree, $6.2 \%$ strongly disagree while $9.2 \%$ are undecided. (Table.05.) 
Table 5. Students need for additional training to fulfill the labor market demands $(\mathrm{N}=1056)$

\begin{tabular}{|r|c|c|c|c|c|c|}
\hline \multirow{2}{*}{ Question } & \multicolumn{7}{|c|}{ Answers } \\
\cline { 2 - 7 } & SA & A & U & D & SD & Total \\
\hline $\begin{array}{l}\text { After graduation, I need additional } \\
\text { trainings to be well prepared for the } \\
\text { labor market. }\end{array}$ & 346 & 389 & 97 & 158 & 66 & 1056 \\
\hline Percentage & $\mathbf{3 2 . 8}$ & $\mathbf{3 6 . 8}$ & $\mathbf{9 . 2}$ & $\mathbf{1 5 . 0}$ & $\mathbf{6 . 2}$ & \\
\hline
\end{tabular}

SA: Strongly Agree; A: Agree; U: Undecided; D: Disagree; SD: Strongly Disagree

In the question if they agree that employing organizations are satisfied with professional preparation of the University of Prishtina students, most of the respondents agree that employers are not satisfied with their professional preparation and abilities. $15.9 \%$ of the respondents strongly agree, $26.5 \%$ agree, $25.8 \%$ disagree, $9.0 \%$ strongly disagree while $22.8 \%$ are undecided. (Table.06.)

Table 6. Satisfaction of employing organizations with professional preparation of the University of Prishtina students $(\mathrm{N}=1056)$

\begin{tabular}{|l|c|c|c|c|c|c|}
\hline \multirow{2}{*}{ Question } & \multicolumn{7}{|c|}{ Answers } \\
\cline { 2 - 7 } & SA & A & U & D & SD & Total \\
\hline $\begin{array}{l}\text { Employing organizations are not } \\
\text { satisfied with professional } \\
\text { preparation of the University of } \\
\text { Prishtina students. }\end{array}$ & 168 & 280 & 241 & 272 & 95 & 1056 \\
\hline Percentage & $\mathbf{1 5 . 9}$ & $\mathbf{2 6 . 5}$ & $\mathbf{2 2 . 8}$ & $\mathbf{2 5 . 8}$ & $\mathbf{9 . 0}$ & \\
\hline
\end{tabular}

SA: Strongly Agree; A: Agree; U: Undecided; D: Disagree; SD: Strongly Disagree

A large number responded that are "undecided" may be due to the lack of the experience of the respondents with the labor market and job interviews.

Student's answers to this question show the reason why interviewed students think that they should undertake additional training in order to be prepared for the labor market. Their response that employing organizations are not satisfied with UP student's professional preparation show that the respondents recognize the need for additional training in order to fulfill the labor market demands and get a job.

This is shown also in the strategy for higher education 2005 - 2015, when it says that some of the problems of quality assurance in the higher education system at the UP are the lack of preparation and ability of students to function effectively in the labor market, discrepancy between the curricula (plan and program) and the labor market needs, as well as a lack of an effective internship program which is not yet functional for all students of the UP. The results endorse the supporting hypothesis and therefore confirm the main hypothesis. 


\section{Conclusion}

One of the priorities of developing the higher education is developing a full functional infrastructure for higher education. One of the measures to achieve this objective is by creating a system of student career development. The results of the research show the existing situation regarding the level of professional preparation of the student of the University of Prishtina and the need students have for career development for improve effective access to the labor market.

The strategy of higher education development 2005 - 2015 that was approved in 2004 came as a result of the need for transformation, reformation and development of higher education in the conditions of new realities and new challenges.

This strategy clearly states the measures that should be undertaken in order to achieve the goals set as a priority for increasing the quality in higher education institutions. However the lack of implementation of this strategy has resulted in students not being ready to enter the labor market after graduation. As a consequence of the strategy of higher education not being implemented it is clear that Faculties of the University of Prishtina lack the monitoring structures of the teaching and learning quality. The need for those structures is as big as the quality assurance in the Faculties contributes to the preparation of students for the labor market.

On the other hand this impacts the practical part of studies, internships, as departments of the University do not incorporate their teaching programs with labor market demands.

This brings a discrepancy between employer's criteria and student's professional preparation, and an increasing desire of students to study abroad, which directly influences falling quality at the University of Prishtina.

\section{References}

Abrahart and P. Verme (2001): Labor Market Policies: Theoretical Background: Chapter 2, Asian Development Bank.

Aleanca Kosovare e Biznesit (2010): Hulumtimi i Nevojave të Tregut të punës, Prishtinë.

Grup autorësh (2004): Raport i sektorial $i$ zhvillimit hapësinor për sektorin e arsimit, Arsimi në Kosovë.

HD and PREM Labor Market Teams (2009): How should labor market policy respond to financial crisis?, World Bank.

Ministria e Ekonomisë dhe Financave, Korniza afatmesme e shpenzimeve, 2010-2012.

MASHT, MTI, MPMS, “Shih mundësitë dhe shfrytëzoj ato!”, Strategjia kombëtare për arsim dhe aftësim në ndërmarrësi.

Ministry of Labor and Social Welfare (2010): Employment Promotion, performance Report, Prishtina. 
Ministry of Education, Science and Technology, Kosovo (2006): Youth Employment Work Plan, 2006-2009, Prishtina.

Pratt, Christopher EdD and Cochran Pratt, Jimmie, MPA from the "New Generations of Global Entrepreneurs "Global Citizenship Through Work-Integrated Learning in the New Economy "(Volume 42, Number 2, ISSN: 1933-2130, Journal of Cooperative Education and Internships).

Riinvest (2003) Institute for Development Research, Labor Market and Unemployment in Kosova, Research Report, Prishtina.

Riinvest (2004): Education and Economic Development Kosova, Draft, Prishtina

World Bank (2003): Kosovo labor market study: Policy callengesof formal and informal employment, Washington.

Metodički obzori 7(2012)3

Prethodno priopćenje

UDK: 331.548-057.87(497.115Priština)

Primljeno: 7. 11. 2011

\section{VAŽNOST I UTJECAJ USLUGA ZA KARIJERU U \\ PRIPREMI STUDENTATA PRIŠTINSKOG SVEUČILISTA ZA TRŽIŠTE RADA}

Ass. Arlinda Beka, MSc Učiteljski fakultet, Prištinsko Sveučilište Rukovodilac, Centar za razvoj karijere Priština, Republika Kosovo e-mail: arlinda.beka@gmail.com

Elmedina Nikoçeviq, MSc

Savetnica za karijeru Centar za razvoj karijere, Prištinsko Sveučilište Priština, Republika Kosovo e-mail: elmedinan@gmail.com

\section{Sažetak}

Razvoj karijere studenata Sveučilišta u Prištini je vrlo važan i potreban faktor za njihovu profesionalnu pripremu. Do prije 7 godina, studentima se nije nudila bila kakva pomoć u savjetovanju ili bila koja praktična pomoć koja bi im pomogla u profesionalnoj pripremi za tržište rada.

S otvaranjem prvog Centra za razvoj karijere, na Sveučilištu u Prištini počelo je i podizanje svijesti studenata za razvoj karijere i istodobno, studenti su počeli da shvaćaju važnost profesionalne pripreme prije nego što pristupe tržištu rada.

U ovom radu se predstavlja istraživanje provedeno s studentima prve do treće ili četvrte godine I ciklusa studija (Bachelor). Cilj ovog istraživanja je potvrđivanje uloge i utjecaja usluga Centra za razvoj karijere u profesionalnoj pripremi studenata.

Ključne riječi: studenti, stručna praksa, tržište rada, nastava 